\title{
穊骨洞に原発した腺癌の一症例
}

一当科にわける穊骨洞癌集計的観察一

$\begin{array}{lll}\text { 出島 } & \text { 健司・水越 } & \text { 文和・西村 秀夫 } \\ \text { 橘 正芳・水越 治 }\end{array}$

\section{Case Report and Survey of Patients \\ Treated Adenocarcinoma of the Ethmoid \\ Sinus in Our University since 1964}

\author{
Kenji Dejima, Fumikazu Mizukoshi, Hideo Nishimura, \\ Masayoshi Tachibana and Osamu Mizukoshi \\ (Kyoto Prefectural University of Medicine)
}

This is a case report of a 68-year-old male with tumor of the ethmoid sinus diagnosed histologically as adenocarcinoma. The patient had complained of nasal bleeding and was treated with surgery, followed by irradiation, chemotherapy and intraarterial infusion of 5FU. The most important part of the treatment was considered to be surgery. The patient is alive 7 months after the initial treatment without any evidence of recurrence of the tumor.

From 1964 to 1984,182 patients with carcinoma of the nasal cavity and paranasal sinuses were treated in our university. In 9 cases $(4.9 \%)$, the primary site was an ethmoid sinus. The histological diagnoses were squamous cell carcinoma (5), undifferentiated carcinoma (3) and adenocarcinoma (1). The 5-year survival rate was $50 \%$, but in cases of undifferentiated carcinoma, or when the eyes were involved, the prognosis was very poor, none of these patients survived for 5 years.

Key words: ethomoidal cancer, adenocarcinoma, combined therapy

はじめに

鼻副鼻腔癌腫は, 耳鼻咽喉科領域の悪性腫瘍 のうち約 $25 \%$ 占め, 喉頭癌に次いで多い疾患 である。その大部分は上顎洞に発生し，他の部 位に発生することは比較的少ないと言われてい る. また, 病理組織像を見てみると, 大半が扁 平上皮癌であり，腺癌は稀之されている，今
回，我々は篩骨洞に原発した腺癌の一症例を経 験したので，当科における最近 20 年間の篩骨洞 癌腫の集計的観察とと屯に，乙こに報告する。

\section{症例}

—68歳 男性

主 訴: 右鼻出血.

初診日：昭和59年 9 月 20 日. 
家族歴 : 父, 胃癌. 弟, 喘息.

既往歴：60歳時, 十二指腸潰瘍に罹患.

現病歴：昭和 59 年 9 月 10 日に特別の誘因なく 突然右鼻出血出現. すぐに止血したが, 以後頻 回に右鼻腔より出血を認めたため，9年18日近 医耳鼻咽喉科を受揨, 右副鼻腔病変を指摘され た. 9 月20日精査目的で当科紹介となった。

初診時所見 : 右鼻腔には, 中鼻道から中鼻甲 介・嗅裂にかけて腫瘍が充満し，鼻中隔を左方 へ压排していた。腫瘍は黄白色で表面不整, 屯 ろく, 易出血性でところどころ凝血塊が見られ た．頸部リンパ節は触知しなかった．煩部腫脹 - 流涙・複視・眼球突出・鼻根部腫脹といった 症状は認めず，また，犬歯窝・口蓋にも異常は なかった，その他，特に全身所見に異常を認め なかった。

画像診断所見：副鼻腔レ線像（図 1）では, 右上顎洞及び篩骨洞に一側性の陰影を認めた が, 明らかな骨欠損の所見はなかった。 C T

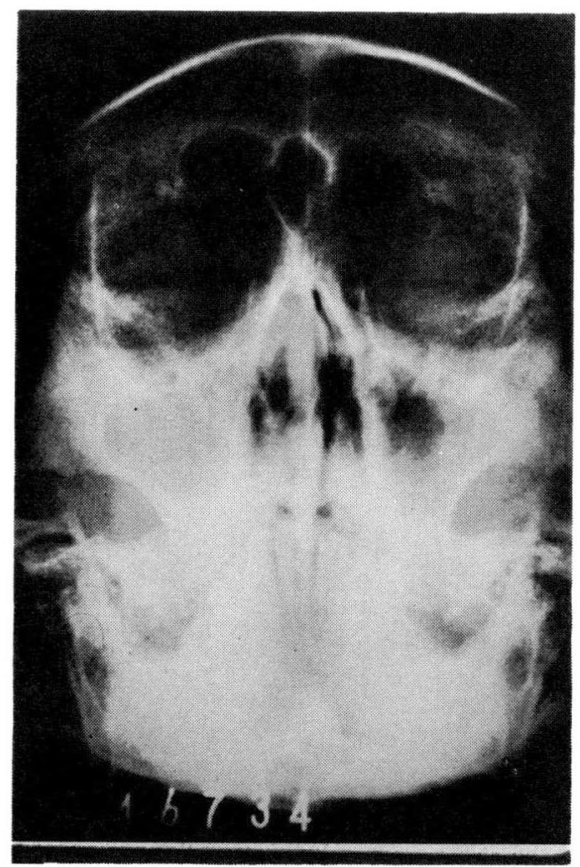

図 I 初診時レ線像（Waters 氏法） 右上顎洞から節骨洞に一側性の陰影を羝めた
（図 2 ）では，前後篩骨洞・鼻腔上部・上顎洞 内側上部に腫瘍を思わせる陰影を認めた。蝶形 骨洞, 眼窩, 頭蓋底, 対側鼻副鼻腔への腫瘍の

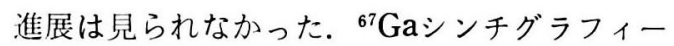
では右上顎洞から穊骨洞にかけて集積を認め た.

治療及び経過：上記所見より，頻度的には上 顎癌が最も考えられるが, 腫瘍の位置・レ線上 骨欠損所見がないところから典型的とは考えに くかった. 10 月 2 日入院の上, 鼻腔内腫瘍より 生検を行い腺癌之の絬果を得, 副鼻腔原発との 診断のもとに，第 1 回目手術で腫瘍全摘を目指 すといった手術にかなり重点を置いた三者併用 療法を施行した。治療経過は図 3 のとおりであ る.

手術は，上顎部分切除術ののち，局所清掃術 を 3 回行った。10月15日に施行した第 1 回目の 手術では，拡大デンケル氏法による上顩部分切 除を行い, 腫瘍は篩骨洞から鼻腔上部に進展し ていた。蝶形骨洞に腫瘍は存在せず，眼筒壁に は異常老認めなかった。上顎洞内は内上側飞肉

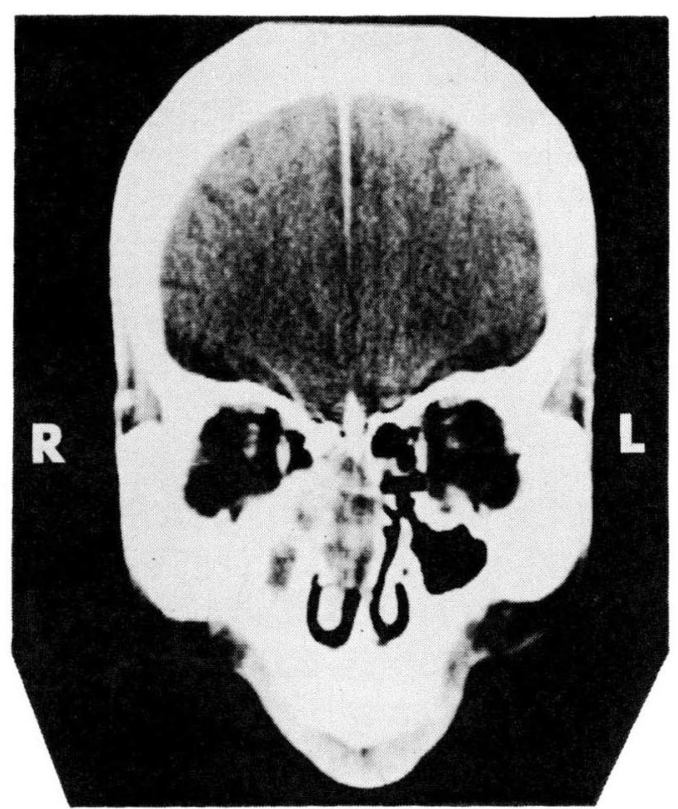

図 2 初影時 C T 
芽を伴った慢性炎症所見で，内容は粘膿性の液 体であった。明らかな骨欠損の所見はなかっ た. 以後 3 回の局所清掃術では腫瘍を認めず, 壊死組織の清掃に終った。病理検査にてむ同様 の結果を得ている。

放射線療法は ${ }^{60} \mathrm{Co}$ による照射で，1 回線量 200rad で週 5 回，計 6 週で総量 6000rad を照 射した。

化学療法は手術日及びその翌日を中心に計 9 回の F AM P AM（5F U250mg，エンドキサン $100 \mathrm{mg}$, マイトマイシンC $2 \mathrm{mg}$, ペプレオ $5 \mathrm{mg}$, MD S 300mg，アドナ200mg）在点滴静注した。 動注は, 第 1 回目手術より 12 日間にわたり浅 側頭動脈よりインフュージョンポンプ (Model PIP 21 : SHARP) で顎動脈系へ，5F U2500 $\mathrm{mg}$ ，ウロキナーゼ12000単位（総量）を注入し た，治療経過中，特に重大な副作用なく，すべ てのスケジュールを終え 1 週間後の 12 月 3 日に 患者は退院の運びとなり， 7 か月後の現在再発 なく良好に経過している。

病理組織学的検査: 第 1 回手術時に上顎洞 . 節骨洞・鼻腔・蝶形骨洞より摘出した組織は病 理検查に提出した。図 4 は, 篩骨洞より採取し た病理標本の H E 染色であるが，濃染性の異型 な核を持つ腫瘍細胞が存在し，一部腺管構造を 構築していた。図 5 は同じくPAS染色で, P A S 陽性物質が染まり，乙れは腺癌を支持す る所見であった．同様の所見が，鼻腔上部の腫 瘍からも得られたが，上顎洞及び蝶形骨洞にお ける病理所見では，このような腫瘍細胞は存在

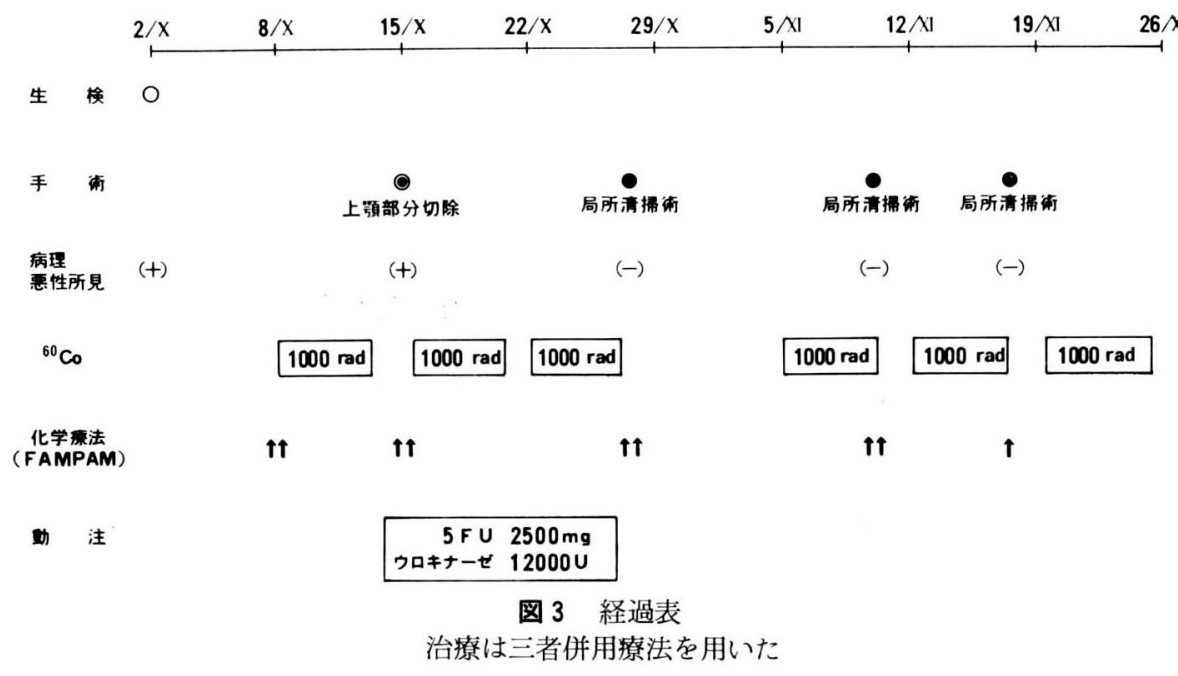

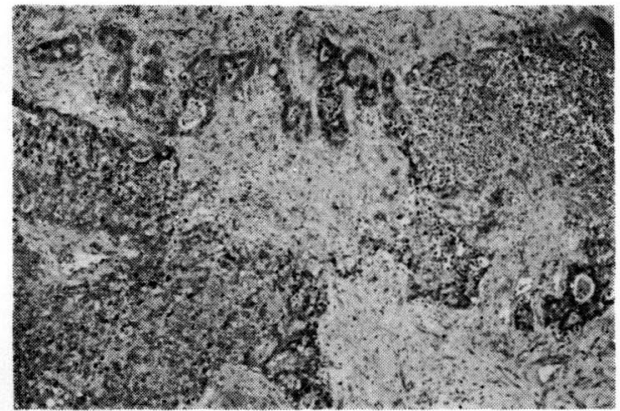

図 4 病理組織学的所見（H E染色）

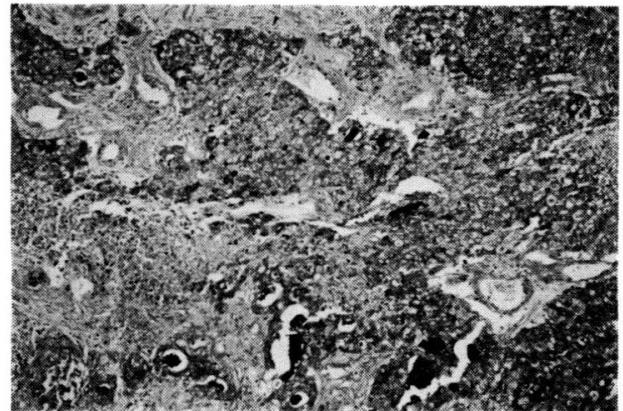

図 5 病理組織学的所見 (PA S 染色) 
しなかった，以上のことから，右節骨洞に原発 した腺癌と診断された。

\section{当科における篩骨洞癌の集計的観察}

当科に昭和 39 年から昭和 59 年までの 20 年間に 訪れた鼻副鼻腔癌腫は 182 例でその内訳は表 1 の通りである．上顎癌が165例 (90.7\%) と压 倒的に多く，篩骨洞癌は 9 例 $(4.9 \%$ ) であっ た。外国の文献によれば，Osbornら ${ }^{1) （ 1961 ） ~}$ は副鼻腔癌腫94例中穊骨洞原発であったものが 31例 (33\%), Lewis ${ }^{2)}$ (1972) は474例中同じ く63例 (13\%), Jacksonら ${ }^{3)}$ (1977) は115例 中同じく15例 $(13 \%)$ であったと述べている. 本邦では，小林ら4) (1966）が 385 例中同じく 13例 $(3.4 \%)$ ，酒井ら ${ }^{5)}$ (1975) が 908 例中 33 例（3.6\%）であったと報告している。

一般に本邦における鼻副鼻腔癌腫中，節骨洞 癌の割合は $3 \%$ 前後とされ, 外国の報告に比べ てその割合は低い。当科における結果は，ほぼ
本邦の報告に一致するあのである.

病理組織学的分類を表 2 に示す。上顎癌では 扁平上皮癌が圧倒的に多く，次いで未分化癌・ 腺様囊胞癌等がめだったが，篩骨洞癌では，扁

表 | 鼻副鼻腔癌腫 (京都府立医科大学耳鼻咽喉科教室 昭和 39 年～昭和 59 年)

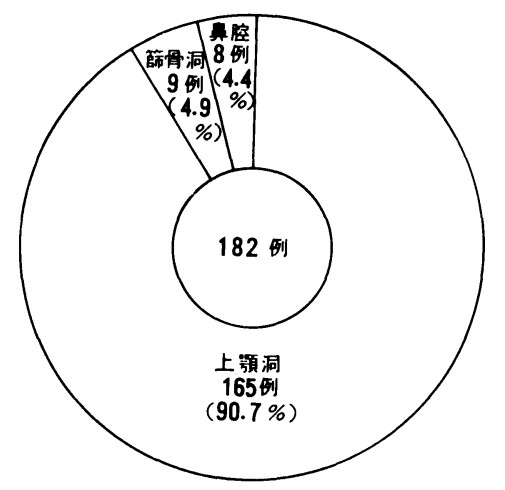

表 2 病理組織学的分類

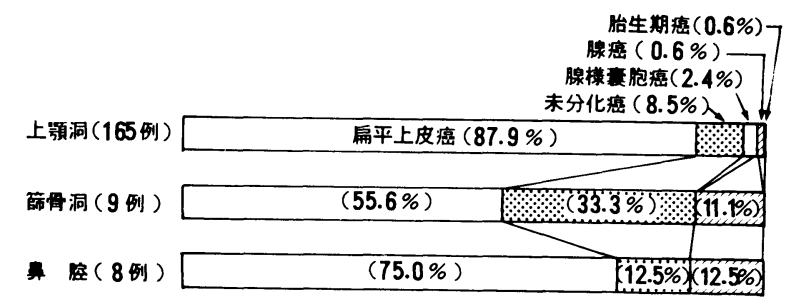

表 3 篩骨洞癌腫

(京都府立医科大学耳鼻咽喉科 昭和 39 年 昭和59年)

\begin{tabular}{|c|c|c|c|c|c|c|c|}
\hline 症例 & 年令・ & & 病 理 & TNM* & 訴 & 治 & 予 \\
\hline & & $\delta$ & 扁平上皮癌 & $\mathrm{T}_{3} \mathrm{~N}_{0} \mathrm{M}_{0}$ & 鼻 根 部 腫 脹 & 手 (上䫈全摘) ·放・ · & 5 年 生 \\
\hline & 59 & q & " & $\mathrm{T}_{2} \mathbf{N}_{0} \mathbf{M}_{0}$ & 頼 部 疼 & 手 (上頻全摘) - 放 - . & 5 年 生 \\
\hline & 59 & ㅇ & " & $\mathbf{T}_{2} \mathbf{N}_{0} \mathbf{M}_{0}$ & 煩 部 腫 脹 & 手 (上頢全摘) ・放. & 不 明 \\
\hline & 38 & $\delta$ & " & $\mathrm{T}_{3} \mathbf{N}_{0} \mathbf{M}_{0}$ & 虽出血. 眼球突出 & 手 (上頴部切) - 放 - 化 · & 6 ケ月死 \\
\hline & 55 & q & 末分化癌 & $\mathbf{T}_{4} \mathbf{N}_{0} \mathbf{M}_{0}$ & 眼 球 突 出 & 手 (試開のみ) ・放・ & 1 ケ月死 \\
\hline & 55 & q & 扁平上皮癌 & $\mathbf{T}_{3} \mathbf{N}_{0} \mathbf{M}_{0}$ & 頓部知覚異常 & $\begin{array}{l}\text { 辛者併用 } \\
\text { 上瀕部切) ・放・化·動注 }\end{array}$ & 5 年 生 \\
\hline & 14 & $\hat{\delta}$ & 末分化癌 & $r-T_{1} N_{2} M_{0}$ & 頸 部 腫 瘤 & ·放・化・ & 3 ケ月死 \\
\hline & 47 & $\delta$ & $"$ & $\mathrm{~T}_{4} \mathrm{~N}_{0} \mathrm{M}_{0}$ & 畐出血・鼻根部腫脹 & - ·化. & 現在11ケ月生 \\
\hline & 68 & $\delta$ & 癌 & $\mathrm{T}_{2} \mathrm{~N}_{0} \mathrm{M}_{0}$ & 出 & 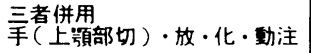 & 現在 7 ケ月生 \\
\hline
\end{tabular}

*酒井試案7) (1971) 
平上皮癌は $55.6 \%$ と減少し, 未分化癌・腺癌の 割合が高くなっている。乙れは犬山ら6)（1973） の報告に一致するあのである．

次に当科に打ける最近 20 年間の穊骨洞癌腫 9 例を表 3 に示す，男女比は $5 ： 4$ でほぼ同率で あった，発症年令は，50才台にピークがみら れ, 平均50.4才であった。 T NM分類は, 酒井 試案7)（1971）を用いた。再発例 1 例を除く と, $\mathrm{T}_{2}$ が 3 例, $\mathrm{T}_{3}$ が 3 例, $\mathrm{T}_{4}$ が 2 例であっ た。辻本ら ${ }^{8)}$ （1983）によると，篩骨洞癌33例 中 $\mathrm{T}_{4} \mathrm{~N}_{0}$ が13例， $\mathrm{T}_{2} \mathrm{~N}_{0}$ が10例， $\mathrm{T}_{3} \mathrm{~N}_{0}$ が 6 例と報告されている。このように上龥癌が $\mathrm{T}_{3}, \mathrm{~T}_{2}$ が压倒的に多いのに比し, 篩骨洞癌で は $\mathrm{T}_{4}$ の症例が比較的多い。乙れは, 解剖学的 に篩骨洞が狭小であり頭蓋底にも近いためと考 えられる。

主訴は, 鼻出血 - 鼻根部腫脹 - 眼球突出等が めだつ。 犬山ら6)（1973）の報告によると，篩 骨洞癌での主訴は, 鼻閉・鼻出血の頻度が高 く, 次いで眼球突出・鼻根部または内㫮部腫脹 が多いが，上顎癌にかなり特徵的な歯痛・煩部 腫脹が殆ど見られないとしている，当科におけ る 9 例では， 3 例が煩部症状を主訴として来院 している。これらはいずれも上顎洞内に慢性炎 症所見を認めており，煩部症状により初発した 穊骨洞癌にも注意すべきであろう。

治療は， $T_{4}$ 或は再発例を除くと, 手術療法 を主体とした。昭和 40 年代の最初の 3 例は，上 顎全摘を行い, 昭和 49 年の第 4 例以降は_上顎部 分切除を行っている．放射線療法や化学療法も 併用療法として行っていることが多い. 一般に 予後は悪いとされるが， 5 年間 follow しえた 6 例では 5 年実生存率は $50 \%$ であった。当科に おける集計では，予後は主に組織型と進行度に より左右されている. 即ち, 未分化癌及び眼症 状を呈したものが予後は悪く, 5 年実生存率は $0 \%$ あった. 以上, 当科に打ける最近 20 年間 の節骨洞癌腫 9 例を提示し, 若干の集計的観察 を加えたが，ほぼ諸家の報告に一致するもので あった。

\section{節骨洞腺癌についての考按}

篩骨洞腺癌は極めて稀な疾患で, 鼻副鼻腔癌 腫中その占める割合は，酒井ら ${ }^{5)}$ (1975）によ ると0.3\%，小林ら ${ }^{4)}(1960)$ によると $0.4 \%$ と 報告されている，本邦において，腺癌のみの報 告例は少なく，その疫学・臨床像・治療方針等 に関する系統だった報告はみられない。

一般に篩骨洞癌の治療には，手術と放射線療 法との併用或はそれに化学療法や免疫療法を加 えたものが良い適応とされている．しかし，篩 骨洞癌の中でも腺癌となるとその放射線療法に 対する感受性は低くなる. Ellingwood ら

（1979）は，穊骨洞・蝶形骨洞・鼻腔原発癌腫 （主として扁平上皮癌）に対して放射線単独療 法で56\%の局所制御率を得たと報告している が, Saunders ら ${ }^{10)}$ (1976) は穊具洞腺癌に対 する放射線療法は殆ど効果なく，腫瘍の消失を みたものは16例中 1 例であるとしている。 ての ように篩骨洞腺癌はあまり放射線感受性がな く，また有効な化学療法剂屯少ないことから手 術療法が優先されることになる，本症例でも上 述の様に手術にかなり重点を置いた三者併用療 法を用いた。術前, 鼻腔内腫瘍よりの生検にて 腺癌との結果を得ていたからである。，一方，篩 骨洞は解剖学的位置から前頭蓋窩や眼窩が近 く，十分な安全域をむって腫瘍を全摘するてと は容易ではなく，既に前頭蓋窩や眼窩内へ浸潤 のあるものはなおさらである，加えて，宮本 ら ${ }^{11)}$ (1984) が述へているように，腺癌は浸潤 傾向の強いという特徵も持っていることから, 篩骨洞腺癌に優先的に選ばれる手術療法も限界 があると言わざるを得ない，そこで，現在上顎 癌の治療に汎用されている三者併用療法の意義 が生じてくる，ただ，篩骨洞癌に対する動注は 支配動脈の関係から上顎癌において用いられる 浅側頭動脈は適忍とならないとされており，坊 野ら ${ }^{12)}$ (1977）が眼動脈逆行性動注法を試みて いる．本例においてもとのてとを一応考慮した が, 眼動脈逆行性動注法は眼障害のことも考慮 しなければならず，また手技的にも困難な点も 
あり，施行するには至らなかった。本例ではむ しろ顎動脈支配領域にも癌腫が浸潤していると 思われたので，上顎癌の場合に準じて浅側頭動 脈より逆行性に注入した。

本例ではさらに放射線療法も加えている．前 述の様に腺癌では感受性は低いとされるが, 現 在でも肺, 腎, 子宮頸部の腺癌に対して放射線 療法が有効であるとされており，やはりなお感 受性があると考えたからである. 即ち, 治療之 してはあくまで手術が主体であるが，補助的な 手段として放射線, 動注屯有効と見なしてての ような方法をとった訳である。

症例が極端に少ないため, 篩骨洞腺癌の治療 方針として確立したものは，現在では未だない が, 今回我々は, 上顎癌に準じて三者併用療法 を施行した。現在のところ，患者は再発転移の 兆候なく，良好に経過しているが，今後注意深 く観察していく必要があろう.

\section{結語}

(1)極めて稀な節骨洞に原発した腺癌の一症例 を経験した。治療は, 手術に重点を置いた三者 併用療法を用い, 問題なく経過した。

(2)当科に昭和 39 年から昭和 59 年までの 20 年間 に訪れた鼻副鼻腔癌腫の 182 例中篩骨洞に原発 したものは 9 例 (4.9\%) で, その組織型分類 では扁平上皮癌が 5 例 $(55.6 \%)$ ，未分化癌が 3 例 (33.3\%), 腺癌が今回の 1 例 (11.1\%) であった。その主訴は鼻根部腫脹・鼻出血・眼 球突出がめだち, 予後は, 5 年実生存率で $50 \%$ であった。未分化癌或は眼症状を呈したものは 予後が悪く, 5 年実生存率で $0 \%$ であった。

稿を終えるに当り,御校閲いただいた水越 治教授, 橋 正芳助教授, 西村秀夫講師に深く感謝いたしま す.

本論文の要旨は第29回日耳鼻京都滋賀地方部会にお いて発表した。

\section{美考文献}

1) Osborn DA and Wiston P: Carcinoma of the paranasal sinuses. J Laryngol Otol $75: 387$ $\sim 405,1961$.

2) Lewis JS : Cancer of the nasal cavity and paranasal sinuses. J Laryngol Otol $86: 255$ 262, 1972.

3) Jackson RT, Fitzhugh GS and Constable WC : Malignant neoplasm of the nasal cavities and paranasal sinuses: (a retrospective study). Laryngoscope $87: 726 \sim 736$, 1977.

4 ）小林秀夫, 永瀬邦彦：鼻腔，副鼻腔腫晹の統計的 観察. 耳展 $3: 470 \sim 477,1960$.

5 ) 酒井俊一, 他: 鼻副鼻腔悪性腫煌 908 例の観察. 耳鼻 $21: 859 \sim 884,1975$.

6 ）犬山征夫, 高崎 敬：篩骨洞癌の臨床一文献的 考察を中心として一. 耳鼻臨床 $66: 162 \sim 172$, 1973.

7 ）酒井俊一, 真崎規江：頭頸部悪性腫焬の T N M 分 類，その拡大適用及びコード化した記録法につい ての試案. 日耳鼻 $74: 70 \sim 77,1971$.

8 ）辻本俊弥，他：上䅡洞を除く鼻副鼻腔癌腫一臨床 統計的観察一。目鼻 $86: 149 \sim 154,1983$.

9) Ellingwood KE and Mllion RR : Cancer of the nasal cavity and ethmoid/sphenoid sinuses. Cancer $43: 1517 \sim 1526,1979$.

10) Saunders $\mathrm{SH}$ and Ruff $T$ : Adenocarcinoma of the paranasl sinuses. J Laryngol Otol $90: 157 \sim 166,1976$.

11）宮本永祥, 他：鼻副鼻腔腺癌の 3 症例. 耳鼻臨床 $77:$ 1585 1590, 1984.

12）坊野鳌二, 他：癌の動注同時放射線療法の遠隔成 績(中間報告) と眼冎篩骨の癌への動注法の試み. 日癌治 $12: 549 \sim 554,1977$.

$$
\begin{aligned}
& \text { 原稿到着：昭和 } 60 \text { 年 } 5 \text { 月 } 8 \text { 日 } \\
& \text { 別刷請求先：出島健司 } \\
& \text { 个529-04 滋賀県香郡木之本町大字黒田 } 1221 \text { 番地 } \\
& \text { 湖北総合病院耳鼻咽喉科 }
\end{aligned}
$$

